\title{
RECICLAGEM DE LODOS DE ETA NA FABRICAÇÃO DE PISOS INTERTRAVADOS (PAVERS)
}

\section{Marcela Ehalt Graciano (FURB); Rodrigo Catafesta Francisco (PPGEA/FURB); Joel Dias da Silva (PPGEA/FURB).}

\section{INTRODUÇÃO}

Problemas relacionados ao tratamento e disposição final de lodos de Estações de Tratamento de Água (ETA) são cada vez mais objeto de estudo por especialistas. No ramo da construção civil, é possível agregar tais resíduos na confecção de tijolos cerâmicos ou até mesmo em argamassas, mostrando-se como uma alternativa viável para solucionar a disposição final deste resíduo, conforme mencionam Tartari et al. (2011, p.293). A aplicação de lodo em argamassas e concreto pode melhorar as propriedades físicas e mecânicas, bem como, reduzir o consumo de cimento Portland nas combinações. Neste sentido, este trabalho contempla aspectos metodológicos para a produção de pisos intertravados (pavers) para uso externo.

O estudo foi realizado na ETA II, em Blumenau, com capacidade de produção de 840 Ls-1 de água para abastecimento público. A ETA II é uma estação de tratamento de água do tipo convencional, onde a maior parte dos resíduos gerados pelo processo de tratamento da água são provenientes dos decantadores e filtros.

\section{METODOLOGIA}

Os galões foram armazenados em local ventilado, com proteção de intempéries, para que o lodo pudesse sedimentar-se, e aos poucos, a desidratação parcial do mesmo pudesse ser feita. Após boa parte da porção de umidade ter sido retida através de um sistema de sucção, amostras do material foram divididas em 3 recipientes e levados a estufa por $24 \mathrm{~h}$ à uma temperatura de $110^{\circ} \mathrm{C}$, resultando em uma desidratação total do lodo. Em seguida, calculou-se a umidade do material, para que esse teor de água pudesse ser aproveitado no traço, diminuindo a quantidade necessária a ser introduzida na mistura.

\subsection{Procedimento Experimental}

Foram coletados, com o auxílio de um recipiente, aproximadamente $250 \mathrm{~L}$ de lodo, inseridos em 3 galões cilíndricos forrados com saco plástico preto, conforme visualizado na Figura 1.

Figura 1. Coleta de lodo

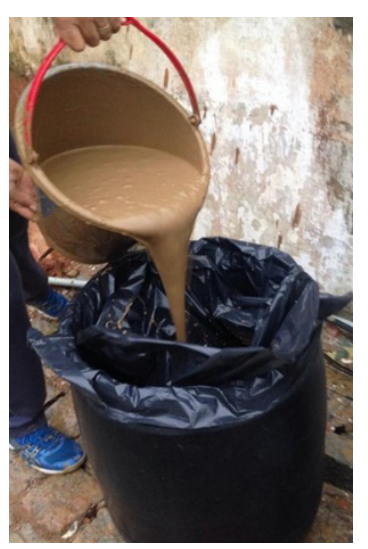

\subsection{Caracterização Físico-Química do Lodo}

Com o intuito de avaliar padrões toleráveis para descarte do lodo e constatar possíveis componentes para o aproveitamento do material, uma amostra de $2 \mathrm{~L}$ foi enviada a um laboratório externo para realização de análises do $\mathrm{pH}$, turbidez, sólidos suspensos e totais, demanda química de oxigênio e concentração de alumínio pudessem ser realizadas. Seguindo-se as diretrizes prescritas na NBR 7.181:84 (ABNT, 1984) uma amostra desidratada do material passou por um processo de peneiramento, para a realização de análise granulométrica. 


\subsection{Preparação dos pavers}

Os materiais usados para a confecção dos pavers foram: cimento CPV-ARI Portland, areia britada e água. Foram seguidas as recomendações da NBR 9.781:13 (ABNT, 2013), buscando uma precisão dimensional e que os padrões mínimos relacionados às características de um paver fossem atingidos. O traço utilizado foi de 1:5:5 de cimento, areia e água respectivamente. Preparou-se, também, um lote de blocos feitos tradicionalmente, apenas com cimento, areia e água em sua constituição para fins de comparação. No preparo das peças com 4, 8 e 12\%, determinou-se a quantidade de lodo a ser substituída na parte da areia através da pesagem da porção da mesma na amostra pura. Posteriormente, calculou-se a porção necessária de lodo a ser agregado ao traço através da Equação 1:

$$
\mathrm{Pl}+\mathrm{U}=\mathrm{Pa} \text {.(\%incorporação) (Eq. 1) }
$$

\section{Onde:}

PI é o peso do lodo a ser agregado à porção de areia da amostra

Pa é o peso da amostra de areia do traço dos blocos da amostra pura

U é a umidade da amostra

\%incorporação é porcentagem de incorporação de lodo na porção de areia do traço das respectivas amostras $(4,8$ ou $12 \%)$

Como a umidade natural do lodo foi aproveitada no traço, desconsiderou-se o teor de umidade de cada amostra em relação a porção de água a ser acrescentada. Confeccionados os respectivos traços, estes foram despejados em uma prensa específica para que fossem moldados e logo iniciassem sua cura.

Depois de 28 dias após a confecção de todos os blocos, ensaios e testes foram realizados para averiguar o resultado do processo.

\section{CONSIDERAÇÕES FINAIS}

Baseando-se na NBR 9.779:12 (ABNT, 2012) e na NBR 5.739:07 (ABNT, 2007) foi possível averiguar, em ordem, a absorção de água por capilaridade e resistência a compressão dos pavers. Ensaios de lixiviação e solubilidade foram efetuados seguindo-se a NBR 10.005:04 e NBR 10.006:04 (ABNT, 2004) respectivamente, e serão objeto de estudo em artigo posterior.

Diante do exposto, verifica-se que, desenvolvimento de soluções que sejam ambiental e economicamente viáveis, para tratamento e disposição final dos lodos provenientes das Estações de Tratamento de Água, apresenta-se como expectativa para transformar o resíduo em recurso.

\section{REFERÊNCIAS}

1. ASSOCIAÇÃO BRASILEIRA DE NORMAS TÉCNICAS. NBR 5.739. Cimento Portland- Ensaio de compressão cp cilíndrico. Rio de Janeiro, 2007.

2. . NBR 7.181: Solo-Análise Granulométrica. Rio de Janeiro, 1984.

3. NBR 9.781: Peças de Concreto para Pavimentação. Rio de Janeiro, 2013.

4. NBR 9.779: Argamassa e Concreto Endurecidos. Rio de Janeiro, 2012.

5. NBR 10.005: Procedimento para Obtenção de Extrato Lixiviado de Resíduos Sólidos. Rio de Janeiro, 2004.

6. NBR 10.006: Solubilização de Resíduos Rio de Janeiro, 2004.

7. BRASIL. Lei no. 12.305, de 2 de agosto de 2010. Institui a Política Nacional de Resíduos Sólidos. Brasília/DF

8. TARTARI, R.; DÍAZ-MORA, N.; MÓNDENES, A. N.; PIANARO, S. A. Lodo Gerado na Estação de Tratamento de Água de Taanduá, Foz do Iguaçú, PR, com Aditivo em Argilas para Cerâmica Vermelha. Parte I: Caracterização do Lodo de Argilas do Terceiro Planalto Paranaense. Foz do Iguaçú/ PR, 2011. 